\title{
Historical Memory , Symbolic Marketing and Racial Cultural Identification in Reggae Music
}

\author{
Yang Dongli* \\ Associate Professor, School of History and Culture, Shandong University, China
}

*Corresponding author: Yang Dongli, Associate Professor, School of History and Culture, Shandong University, China

Received Date: November 05, 2021

Published Date: November 16, 2021

\begin{abstract}
Reggae is unique in contemporary western popular music. This music took shape from the styles of Creole, Rastafari, Mento, R\&B, Ska, Rocksteady, etc., with historical memories of Africa culture and colonial slave culture, and bred black cultural identification, as well. Reggae's black identification developed trans-race, trans-class and trans-region mode under reggae musician's keen innovation and black-white audience's positive participation. Reggae marketing symbolic system constructed by black dressing, creole language, reggae element and rastafari made contribution in the process. Reggae thus presented significances of black cultural identification in consuming society, such as anti-racial and anti-class pressure, national identification, cultural integration, etc.. Reggae case could provide inspiration for building for national cultural identification with modernity spirit in the age of globalization, while, its negative effect should not be neglected.
\end{abstract}

Keywords: Cultural memory, Symbolic marketing, Consuming society, Racial identification, Reggae

\section{Introduction}

Reggae music is considered to represent the vigorous life vitality and mysterious life fable from distant Africa, which is unique in contemporary European and American pop music. However, it is not pure African music, but a product of long-period integration of African music and white music in Jamaica slave market. However, due to the connotation of African historical memory, reggae music is generally regarded as the representation and continuation of African black culture in consumer society. The discussion on the relationship between reggae music and black identity in consumer society can not only enable us to get a clear and profound understanding of construction mode and communication path of contemporary black culture, but also provide reference for national construction of cultural identity and handling the relationship with black culture in the context of globalization.

\section{Cultural Memory of Reggae Music and Black Racial Identity}

The racial identity of blacks in consumer society cannot be directly reflected in occurrence, dissemination, and acceptance of reggae music, but mainly in the form of reggae music cultural memory. Therefore, the reflection on the black racial identity in reggae music is actually a reflection on the black cultural memory of reggae music.

The Assmanns in Germany pointed out that the connotation of cultural memory is that culture is a kind of memory, because on the one hand, culture will create the common life vision of ethnic groups through symbolic symbols; on the other hand, it will continue to accumulate, inherit, and spread in the historical development. Cultural memory is of great significance for maintaining ethnic groups and ethnic identity. As an imaginary community, its members will firmly believe in their shared history, culture, or ethnic origin. The mutual recognition and cohesion of ethnic members based on ancestral memory is ethnic identity.

The cultural memory of reggae music condenses the black ethnic groups at the spiritual and psychological level, while excludes and blocks the ethnic groups outside, and then constructs the black racial identity. This cultural memory has a clear development clue. The origin and evolution of reggae music in Caribbean has a history of more than 400 years. It comes from Creole dialect. Creole 
music was born on the basis of Creole dialect [1]. Creole music is the integration of labor songs sung in Creole dialect, French and Spanish dance music, British folk and religious music in mode, theme, rhythm and structure. It embodies the independent values and organizational rules of Jamaican black music through multi melody, syncopation, accompanying rhythm and speed. It is "a crucial autonomous space of cultural and political freedom" [2].

Although slave owners took various measures to prevent slave music from inheriting African culture, Creole music finally brought African cultural tradition to the era of slave liberation. In 1838 , slavery in Jamaica went bankrupt. Blacks began to boldly integrate African witchcraft forms such as drum music, soul summoning and dance into daily Christian activities such as prayer, hymn singing and Bible reading, which gave birth to Rastafari music that cared about black social problems. In 1930s and 1940s, European Polka, Waltz and Lille dances, especially the accompaniment and performance methods of four cube dances, were absorbed by black musicians and created Mento music. Manto inherited the syncopation and melody mode from early Creole music, reflecting the situation of inland immigrants in the Caribbean in the late 19th century and early 20th century in content, and inheriting the deep-rooted social satire and criticism tradition of African music in style. In 1940s, Jamaica successfully transformed from agricultural society to industrial society. The preference of young people in Jamaica began to shift from Manto to R \& B. They believe that "The harder, electronic rhythms of the urban jump blues and the loping, shuffle tempo of southern R \& B artists like Amos Milburn, Fats Domino and Louis Jordan proved more appealing to working-class Jamaicans"[3]. It can alleviate the pressure of urban life and suit their taste better. Since then, after consciously re-Africanizing and highlighting the resistance against the colonial bourgeois cultural hegemony, slow rock was born. Slow rock "enhanced use of the electronic bass" [4], making "Political and historical themes became more prevalent, conveying an acute awareness of slavery and colonialism and the links between past and present forms of oppression" [5]. Slow rock is the predecessor of reggae. In late 1960s, some young musicians were dissatisfied with the art economy joint production mechanism and launched an art economy autonomy movement. Therefore, music creators had more opportunities to record music with creative and political connotation. Slow rock made great progress in skill exploration and developed into reggae music in 1968.

Comparing with the predecessors, the rhythmic interaction between different Reggae instruments has reached a new level of complexity and interest: melody of the guitar adds an additional half-beat to the Jamaica classic weak-beat, which gives the melody adhesion, and the addition of the keyboard strengthens this feature. At the same time, reggae's omission of bass bars and the occasional pause of bass in Reggae create a special sense of rhythm. Reggae highlights its non-European characteristics through its non pronunciation part and deepens its significance as a black culture, "perform their indigenous identity in ways that stretch beyond the boundaries of their own reservations and tribal nations"[6], cultivating a collective black cultural identity across class, region and race, and reflecting the temperament of confrontation with western classics. Reggae musicians hope to tap the value of black culture associating with the overall development of human society and integrate black culture into the mainstream of world culture. The later realistic expansion of reggae black culture also proves the significance of these musicians' efforts.

\section{Reggae symbol marketing, white audience, and the expansion of black cultural identity}

Reggae's cultivation of cross-class, cross-racial and crossregional black cultural identity began with the maturity of its "global" industrial operation mechanism indigenous reggae thrives within the very channels of global capital"[7]. The growth of Jamaica's local record industry in 1960s and reggae's entry into the international leisure industry in 1970s made Reggae obtain a mature international and domestic marketing communication mechanism. With the help of this marketing communication mechanism, reggae went beyond the regional boundary of its production context and began to establish a relationship with the life experience and economic development of African Caribbean communities in Europe and America, especially in British cities.

In 1962, Chris Blackwell imported reggae music for the first time for Jamaican black immigrants who settled in Britain in 1950s. Since then, reggae has taken root and spread widely in Britain. Under Britain's loose policy on black industrial investment and autonomy, reggae's operation in Britain has always been dominated by black autonomy. This kind of operation generally adopts the way of symbolic marketing. Marketing channels include local radio stations, brand direct selling agencies, reggae record stores, independent record stores and a variety of commercial street brand direct selling stores. Through these marketing channels, reggae has spread Reggae's marketing symbols to various public entertainment places such as special bars, cafes, nightclubs, shopping districts, parks, skating rinks, clubs, dance halls and live concerts, creating a unique cultural practice and consumption mode for the black community [8].

Symbolic marketing refers to the scientific analysis of consumer psychology and motivation, and the establishment of appropriate links between certain products and meaning by means of artistic and stylized means, so as to distinguish enterprise products from other similar products, stimulating consumption and promoting product sales [9]. The artistic and stylized means for establishing an appropriate connection between product and meaning are marketing symbols. Marketing symbol is the symbol of entering the commercial marketing process. It, like ordinary symbols, means system. The marketing symbols of reggae music are generally reflected in pictures and photos relating to reggae music and its social metaphorical meaning, as well as Reggae elements such as Reggae singers, lyrics, melodies, musical instruments and playing methods. In addition, they also include black costumes, mixed languages and rastafa. When receiving Reggae's marketing symbols, 
the audience will show different understanding meanings of reggae due to their different understanding of race, life, and other issues. These meanings crisscross together, forming the marketing symbol text of reggae music, and the way the audience uses the marketing symbol is internalized into the potential structure of the text.

With the enhancement of reggae's marketing ability and vitality, its dissemination is no longer limited to the black community, but has entered the white social life. The first white people attracted by reggae music were white teenagers. Most of them live near the black community. Some have black playmates since childhood, some go to school with black teenagers, and some often go to black operated entertainment places out of curiosity. The marketing communication of reggae music to the white community is of course for economic interests at the beginning, but in the process of communication, it will produce many political and cultural meanings that are not directly related to economic interests.

The marketing symbols of reggae music in white audiences are roughly the same as those in blacks, which are mainly reflected in Reggae elements, black costumes, mixed languages, rastafarism and so on. As mentioned earlier, reggae elements include relevant pictures, photos, lyrics, melodies, musical instruments, playing methods, etc. They are "perhaps most obviously relevant, though, in a more general, class-based manner, as a form of 'reality' or 'rebel' music"[10]. Reggae elements usually do not directly express formed political ideas, but convey values through its consumer fun feelings and expectations of life, and implicit political tendencies.

Black clothing includes black-style shirts, jackets, skirts, narrow legged pants, etc., The colors are mainly "Ethiopian colors of red, green, and gold"[11]. Even white teenagers who have little or no contact with blacks often wear black clothes. However, white teenagers generally do not dress completely "black". Their black clothing usually accounts for only a small part of the overall clothing, such as wearing only a black shirt or jacket, reflecting a little trace of black culture.

Mixed language is a mixture of African language and English. It is not so much a communication discourse between black and white teenagers as communication skill. "Indeed, in some contexts, white creole usage could be instrumental in shaping such friendships, and in mediating black-white relationships across a wide range of social contexts"[12]. The use of mixed language by white teenagers does not absolutely mean that they have established friendship with blacks. In many cases, they express themselves in mixed languages, distinguishing themselves from whites who have not been exposed to black culture. In a sense, this behavior makes them a channel for the dissemination of black culture.

Although Reggae has been constantly learning from various rich musical traditions in Jamaica, rastafa music has the deepest influence on it, which contains "the Rasta themes of peace, solidarity and black pride"[13], constituting a cultural symbol of reggae. At the same time, rastafarism does not set any code of conduct and advocates respect for life force. This enables white teenagers to get religious influence without being bound by religion. Therefore, many white teenagers will take rastafarism as the spiritual guidance of daily life and the ideological basis of micro-political resistance.

\section{White acceptance effect of reggae black cultural identity}

Although black culture can be accepted by white teenagers to a certain extent, and even their marketing symbols can constitute the representation of their self-consciousness, when white teenagers use these symbols in the realistic cultural and political dimension, they will soon find themselves in a highly contradictory social position. This social position has brought them many effects and troubles of potential political fringe. First of all, the acceptance of black culture by white teenagers will form cross racial friendship on the one hand, but on the other hand, it will also arouse the disgust of blacks. The use of black cultural symbols by whites is sometimes seen as a symbol invasion and a new form of racial oppression. Black youth can shout to these white teenagers, "stop acting black" and "you can't be Rasta"[14].

Secondly, once white teenagers make mistakes in their understanding and use of black culture, the consequences will be quite serious. White teenagers use Reggae marketing symbols sometimes to establish cross racial friendship, but sometimes they just find Reggae marketing symbols interesting. This makes it difficult to avoid mistakes. If they use Reggae marketing symbols without establishing intimate relations with blacks, or at the wrong time and place, or in the wrong way, they will be cursed by blacks. "Its use by some young whites as a source of amusement therefore (through caricatured 'funny voices' for example) could be interpreted as a derisive parody of black culture and therefore a form of racist abuse" [15]

Thirdly, the participation of white teenagers in black cultural activities will bring psychological problems to themselves. The participation of white teenagers in black cultural activities is not always smooth sailing, but will encounter various difficulties. The ideal of close friendship between blacks and whites could be "rudely shattered by hostile responses from other young blacks"[16], because on the one hand, white youth can't actually feel the pressure of black youth; and on the other hand, the attitude of black youth towards white youth is very contradictory.

White youth's confidence in their previous ideal of cross racial friendship will be affected, and then fall into self-reflection and doubt. The result of reflection and questioning is that the attitude of white youth towards black culture has changed from unreserved acceptance to acceptance and exclusion. They "caused the prominence of racial boundaries to be continually brought in and out of play"[17]. However, most white young people will not give up Reggae completely, but they will be more obscure when displaying their black cultural symbols, such as wearing black dress flower shirts in their coats or wearing black jewelry in inconspicuous 
places. Of course, white youth generally do not completely identify with black culture at the cost of complete loss of self.

Finally, white youth who love black culture are sometimes excluded by other whites, especially their white companions and relatives. However, even if white children withdraw from their association with blacks and black culture, the pressure still exists. Therefore, white children who like black culture sometimes adopt the strategy of "accepting individual blacks as 'one of us' or 'not really black"' in their contacts with blacks [18]. Of course, the plight of these white children does not mean that it is difficult for children of two races to establish a close relationship. They sometimes face common problems. For example, when the school shapes white children and black children through education at the same time, white children and black children will form a small cross racial group to fight against the authority of the school. In a small group, black youth cultural symbols such as Reggae will have a great attraction to white children. They will use such cultural symbols to resist the school authority, and then form an anti-school culture. However, the relationship between white and black children will change significantly after they graduate from school. In the common tide of unemployment in British society after 1960s, they sometimes become competitors and sometimes help each other.

In short, the participation of white youth in black culture does not mean their acceptance for black and all black culture. The White Youth Association strives to maintain its special understanding and handling for black culture. They should not only maintain their friendship with blacks, but also maintain their independent judgment and avoid being assimilated by black culture. At the same time, they should resist a common sense of collective pressure and racism, but also resist the influence of racial discrimination ideology publicized by national media from time to time. This is an ability accumulated through life experience. Supported by this ability, some white youth will practice anti-racial ideas and ideals and strive to turn them into a real reality. This constitutes the real value of reggae black cultural identity to the white audience.

\section{Multiple interpretations for reggae black cultural identity in context of consumer society}

The interpretation and treatment of reggae marketing symbols by white teenagers presents a variety of complex states. This makes Reggae's black cultural identity possible to obtain multiple interpretations in the context of white dominated consumer society. Therefore, it embodies three meanings: anti-race and anti-class oppression, national identity, and cultural integration. However, these three meanings do not appear at the same time but have a diachronic nature.

The first is the significance of anti-race and anti-class oppression. As mentioned earlier, this significance stems from Reggae's historical memory, but it was particularly prominent in Britain in the late 1960s and early 1970s. At that time, many unemployed black youths were often beaten by the police in the street. Therefore, most black youth have profound feelings about racial discrimination and economic oppression. These feelings developed a clear sense of anti-race and anti-class oppression for reggae music. This consciousness tries to reconstruct the existing order of practical ideology, political tradition and community experience among black people in Britain: "reggae's power and appeal has always depended on its refusal to compromise for a large white audience" [19].

The second is the significance of national identity. In the middle and late 1970s, a vibrant music culture dominated by reggae and dominated by the second and third generations of British black youth was established in the main urban areas of Britain, in which the significance of national identity appeared. At that time, "Organised into units of ten to fifteen members, each with delegated roles and responsibilities, and coordinating a variety of maintenance skills, sounds became a way of life and an important form of cultural self-activity for thousands of black youth [20]. They often get together in youth clubs, disco, nightclubs or Reggae live concerts, and also hold family "blues parties"[21] from time to time. The Reggae tradition in Britain was created in this way. The fast style rap born in 1980s strengthened the local characteristics of reggae, and its representative work Cockney Translation is also the representative work of Reggae in Britain. The song fills with new English words, phrases and language expressions produced by black and white people after many exchanges. This mixed culture tries to surpass the conflict between black and white in Britain, which creates a black British culture and redefines "Britain".

The third is the significance of cultural integration. Reggae in Britain not only constructs cultural dialogue space between black and white youth, but also promotes the cultural integration in the relationship between race and class in contemporary Britain. However, reggae's promotion of cultural integration is quite tortuous. As mentioned earlier, white teenagers do not accept and love reggae on a large scale from the beginning. Even after they accept reggae, there is a repeated process of rejection and reacceptance in view of social politics. In 1970s, reggae, which was introduced into the white community by "skinhead", had achieved great success in communication [22]. However, the unemployment wave and the black-and-white competition in the labor market made white youth's enthusiasm for Reggae fade. Until around 1972, Bob Mali customized the cosmopolitan version of reggae for the white audience. "his songs maintained a political militancy and a counter-cultural quality which appealed deeply to young whites" [23]. However, white fans soon found that the so-called rebellious spirit in the music of Bob Mali and others only played a decorative role and lacked the impact of hitting the heart directly. Driven by white fans, black reggae and white rock merged in 1976. Punk and OI punk are the products of this integration. Punk is a white rock based on great recognition of early reggae Roll. They reshape rock and roll through reggae, so as to criticize the oppressed nature and monotonous and boring characteristics of daily life under 
the capitalist system, and emphasize reshaping local culture and faithfully recording current affairs [24]. Oi punk roots in white working-class teenagers. The music is more simple and direct, even rough, and the songs are also related to their lives. In the late 1970s, polyphonic music was born on the basis of the integration of black and white culture, but it also shows the anti-race and anti-oppression consciousness of black cultural identity and the consciousness of national identity. It shows that white and blacks go to school together, play together in the street, and share the daily experience of community and recreational activities, and it presents the shared social experience of "racism, of police harassment and the dole" [25] as well. In addition, it also directly involves "the wider political issues of youth, race, unemployment and Thatcherism" [26]. On the whole, it expresses the hope of building British local culture on the basis of mutual tolerance and integration of black and white cultures. This makes polyphonic music the most successful reggae music in Britain. After the declining of polyphonic music, reggae music withdrew from the center of British pop music and is only regarded as one of many ethnic minority music.

Nevertheless, reggae's contribution to black cultural identity in the context of consumer society is obvious to all. With the joint efforts of reggae musicians, audiences and reggae symbol marketing system, black cultural identity in consumer society has finally expanded into a realm that transcends race, class and region. "The history of the black Atlantic yields a course of lessons as to the instability and mutability of identities which are always unfinished always being remade" [27]. This has important reference significance for human race to deal with the relationship between self-development and racial conflict in the context of globalization.

\section{Conclusion}

Although Reggae's contribution to black cultural identity in the context of consumer society is obvious to all, we can't ignore the negative impact of reggae on black cultural identity in the context of consumer society. These negative effects are mainly reflected in two aspects: firstly, reggae makes pop music promotion more dependent on black style and image, and then, reggae strengthens the stereotype of blacks as entertainment practitioners, that is, the practitioners of contemporary pop music are mainly blacks, and the jobs of blacks are only limited to pop music. In fact, both contemporary pop music practitioners and black careers are diversified. Secondly, reggae is also easy to make the audience mistakenly believe that all commercial black pop music has the value of black cultural identity, and then ignore the erosion of black cultural identity by pure commercial ideological carriers such as hip hop [28]. The industrializing mechanism of pop music not only makes black cultural identity to a certain extent, but also produces many "pseudo blacks" marked by black cultural symbols and for the purpose of pure money through the dissemination of black music such as Reggae in more countries, regions and ethnic groups pop music, such as hip hop. This kind of pop concert misleads the audience's understanding of black culture, but it can't make them truly identify with black culture. In view of this, while building national cultural identity in the context of globalization, we should pay attention to such problems, avoiding shaping the stereotyped image of national culture in the field of international culture, and being vigilant against the authenticity of national culture by commercialization mechanism corrosion for connotation.

I want to express my gratitude to Professor Wang Yuji for his sincere help for this article.

\section{Acknowledgement}

None.

\section{Conflict of Interest}

No conflict of interest

\section{References}

1. Simon Jones (1988) Creole dialect was created by blacks who were trafficked from Africa to Central America and the Caribbean under the local slavery. It is a new language with African languages mixed with European languages. Black Culture, White Youth : The Reggae Tradition from JA to UK, Macmillan Education Ltd., London, p. 4.

2. Simon Jones (1988) Black Culture, White Youth : The Reggae Tradition from JA to UK, Macmillan Education Ltd, London, p. 9.

3. Simon Jones (1988) Black Culture, White Youth : The Reggae Tradition from JA to UK, Macmillan Education Ltd, London, p. 8.

4. Simon Jones (1988) Black Culture, White Youth : The Reggae Tradition from JA to UK, Macmillan Education Ltd, London, p. 22.

5. Simon Jones (1988) Black Culture, White Youth : The Reggae Tradition from JA to UK, Macmillan Education Ltd, London, pp. 23.

6. Luis Alvarez (2008) Reggae Rhythms in Dignity's diaspora: Globalization, Indigenous Identity, and the Circulation of Cultural Struggle. Popular Music and Society 31(5): 575-597.

7. Luis Alvarez (2008) "Reggae Rhythms in Dignity's diaspora: Globalization, Indigenous Identity, and the Circulation of Cultural Struggle". Popular Music and Society 31(5): 575-597.

8. See Simon Jones (1988) Black Culture, White Youth : The Reggae Tradition from JA to UK, Macmillan Education Ltd, London, pp. 38.

9. Qi Haifeng (2004) Symbolic Consumption and Marketing Strategy, Economic Management, p. 29-34.

10. Simon Jones (1988) Black Culture, White Youth : The Reggae Tradition from JA to UK, Macmillan Education Ltd, London, p. 165

11. Stephen A. King (1999) The Co-optation of a "Revolution: Rastafari, Reggae, and the Rhetoric of Social Control". Howard Journal of Communications 10: 77-95.

12. Simon Jones (1988) Black Culture, White Youth: The Reggae Tradition from JA to UK, Macmillan Education Ltd, London, p. 147.

13. Dick Hebdige (1987) Cut'n'Mix: Culture, identity and Caribbean music, London and New York: Routledge : UK, pp. 61.

14. Simon Jones (1988) Black Culture, White Youth : The Reggae Tradition from JA to UK, Macmillan Education Ltd., London, p. 179.

15. Simon Jones (1988) Black Culture, White Youth : The Reggae Tradition from JA to UK, Macmillan Education Ltd, London, p. 180

16. Simon Jones (1988) Black Culture, White Youth : The Reggae Tradition from JA to UK, Macmillan Education Ltd., London, p. 186.

17. Simon Jones (1988) Black Culture, White Youth : The Reggae Tradition from JA to UK, Macmillan Education Ltd, London, p. 188.

18. Simon Jones (1988) Black Culture, White Youth : The Reggae Tradition from JA to UK, Macmillan Education Ltd, London, p. 198. 
19. Dick Hebdige (1987) Cut'n'Mix: Culture, identity and Caribbean music, Routledge, London and New York, p. 28.

20. Simon Jones (1988) Black Culture, White Youth : The Reggae Tradition from JA to UK, Macmillan Education Ltd, London, p. 43.

21. Family "blues party" is a family party with singing and playing blues as the main entertainment form. Its popularity began in Britain in the middle and late 20th century.

22. From 1969 to 1971, reggae achieved great success in spreading among white audiences. "Double Barrel" by Dave and Ansell Collins became the most popular song of the year. (See Simon Jones (1988) Black Culture, White Youth : The Reggae Tradition from JA to UK, Macmillan Education Ltd, London, p. 60.)

23. Simon Jones (1988) Black Culture, White Youth : The Reggae Tradition from JA to UK, Macmillan Education Ltd., London, p. 94.
24. See Simon Jones (1988) Black Culture, White Youth : The Reggae Tradition from JA to UK, London: Macmillan Education Ltd, p. 97.

25. Simon Jones (1988) Black Culture, White Youth : The Reggae Tradition from JA to UK, Macmillan Education Ltd., London, p. 108.

26. Simon Jones (1988) Black Culture, White Youth : The Reggae Tradition from JA to UK, Macmillan Education Ltd, London, p.108.

27. Paul Gilroy (1993) "Preface" in Paul Gilroy, The Black Atlantic: Modernity and Double Consciousness, Verso Books, London, New York, p. ix.

28. Hip hop is rooted in consumerism, but on the surface, "it also plays an anti-hegemony role because of necessity. Tavia Nyong'o, "Paul Gilroy. Darker than Blue: On the Moral Economies of Black Atlantic Culture". Journal of Popular Music Studies 24(1): 107-113. 